\title{
PRIMEIRO DIÁLOGO
}

Apresentamos à comunidade acadêmica a segunda edição da e-Mosaicos - Revista Multidisciplinar de Ensino, Pesquisa, Extensão e Cultura do Instituto de Aplicação Fernando Rodrigues da Silveira (CAp-UERJ).

Neste segundo número, o artigo encomendado Práticas Docentes em Tempos de Inclusão: uma experiência na escola básica, de autoria de Patrícia Braun e Márcia Marin, apresenta o caminhar de ações de inclusão no Instituto de Aplicação da UERJ com seus avanços e desafios.

A seção artigos permite a reflexão sobre a formação docente a partir da leitura de textos que abordam a formação pelo viés do Programa Institucional de Bolsas de Iniciação à Docência (PIBID) e das reflexões sobre o ensino de Sociologia no Brasil. Apresenta também o lugar ocupado pela disciplina Teatro na escola, um estudo sobre as relações de espaço e tempo nos ensinos Fundamental e Médio, a partir de observações sobre as permanências e dinâmicas históricas, e outro estudo que trata da relação entre Educação de Jovens e Adultos e formação profissional, pela vertente da reestruturação produtiva.

Como resenha desta edição, apresentamos o livro Matemática Financeira para Educadores Críticos, de autoria de Ilydio Pereira de Sá.

As produções realizadas nas aulas de Fotografia do CAp-UERJ compõem a capa. São estudantes fotografados por outros estudantes.

Desejamos a todos e todas uma boa leitura!

Professora Andrea da Paixão Fernandes

Editora Geral 